\title{
Gene flow scenarios with transgenic maize in Mexico
}

\author{
José-Antonio SERRATOS-HERNÁNDEZ ${ }^{1 *}$, Fabián ISLAS-GUTIÉRREZ1 ${ }^{1}$ Enrique BUENDÍA-RODRÍGUEZ1 \\ and Julien BERTHAUD ${ }^{2}$ \\ ${ }^{1}$ Campo Experimental Valle de México, Instituto Nacional de Investigaciones Forestales Agrícolas y Pecuarias, Mexico \\ ${ }^{2}$ Institut de Recherche pour le Développement, France
}

Maize diversity is widespread in Mexico and it has been stewarded by campesinos in small communities until the present. With the arrival of transgenic maize, the objective of this study is to analyze possible scenarios that could result if genetically modified maize were not regulated and openly available in Mexico. By applying a simple logistic model based on the conditions of maize production in Mexico, the dispersion of transgenic maize in different situations within fields of farmers is described. In traditional open systems of freely exchanged seed within communities it is concluded that the most likely outcome of GM maize release is the incorporation of transgenes in the genome of Mexican germplasm and possibly in that of teosinte.

Keywords: maize / landraces / teosinte / transgenes / gene flow / biosafety / GIS / Mexico

\section{INTRODUCTION}

Modern biotechnology is a powerful tool that has increased the capacity of scientists to use and transfer genes between individuals of the same species or from distant unrelated taxa. The exchange of genetic information has been expanded from the basic species to the kingdom level, since natural barriers can be broken through biotechnology. In theory, all organisms on earth could be considered as one gene pool. The possibilities for new developments in industry, agriculture, health and environment are therefore immense. Thus, benefits derived from biotechnology could be great, but at the same time risks must be considered thoroughly since this technology could have a profound impact on the environment and on human activities.

At the onset of biotechnology development, scientists working in this field cautioned about the implications and possible consequences of this technology (Berg et al., 1974). Government agencies in industrialized countries were put in place to regulate biotechnology, and strategies were defined for the assessment and management of the novel products that were released by the new industry. A certain number of factors were identified in order to evaluate the ecological impact of genetically modified plants that could be released into the ecosystem: (1) the possi- bility of a transgenic plant to become a weed through gene flow between crop and wild relatives; (2) development of resistance in pests and pathogens to the GMO; (3) negative impact on non-target organisms; and (4) alteration of ecosystems (Tiedje et al., 1989).

In particular, dangers and risks to the environment identified with the release of transgenic maize are those related to traits or factors with potential negative impact on maize diversity, maize and animal health status, human health, and on campesino** production systems. Among others, potential risks connected to gene flow are the possible hybridization of transgenic maize and teosinte, which could eventually lead to introgression of transgenes promoting generation of forms of weedy teosinte, and the speeding up of evolution of resistant pests to pest control strategies based on transgenic maize.

Mexico is considered the 5th megadiverse country in the world, located in the area of origin, domestication and diversity of many important crops (Harlan, 1992). Therefore, biosafety in Mexico had been considered an important issue that had been cautiously approached because of the lack of precise information on unique dangers to agroecosystems, the effect of genetically modified crops on wild relatives and on diversity of crops. However, some

\footnotetext{
* Corresponding author: aserratos@cgiar.org

** Campesino is defined as a resource poor farmer, cultivating mostly in rainfed land by traditional methods for selfconsumption or small scale market.
} 


\section{J.-A. Serratos-Hernández et al.}

people have argued that there was no need for concern about the interaction between maize, transgenic maize and its closest relative, teosinte (Martínez-Soriano and LealKlevezas, 2000). These opinions were further discussed in warnings about the "largely unknown genetic and ecological risks of introducing transgenic crops into the centers of origin of agronomic crops" (Nigh et al., 2000). In this regard, the objective of this article is to contribute with a systematic analysis and gathering of information related to the known distribution of teosinte, maize local varieties and maize production in the areas of Mexico where sympatric coexistence of these species is known. The information was processed by means of Geographical Information System (GIS), in order to set up scenarios for risk assessment, monitoring and generation of working hypotheses on gene flow interactions between local landraces of maize, teosinte, and transgenic maize. This information could be useful for risk assessors and research scientist interested in studying or setting models for the dynamics of teosinte-maize and maize-maize interactions.

\section{MATERIALS AND METHODS}

\section{Database}

The information on maize production per district in Mexico was kindly provided by Hyman and Rodriguez from CIAT and CIMMYT, respectively. The database used in this study is part of a broader project carried on at the Natural Resources Group of CIMMYT, and CIAT (Hartkamp et al., 2000; Hyman et al., 1998) and was used to illustrate the production of maize in a given year. In the present study the information was related to production of maize per district in 1995. Because the production of maize could be variable at each specific location within a district, the production data and area planted to maize was used as representative of the whole municipal area. In this case we over-represent the area of production of maize in each district because not all the area is sown to maize; however, production figures identify accurately the amount of maize produced in the area as a whole, regardless of the specific site of production.

The database for maize landrace location was downloaded from the Latin American Maize Project data CD-ROM (LAMP, 1992). The landraces were selected according to the primary landrace name provided in the program, which corresponds to the classification made by Wellhausen et al. (1952), and still used as reference in studies of maize taxonomy in Mexico (Sanchez-Gonzalez and Goodman, 1992a, b). Recent studies have used the same nomenclature as standard for maize landrace recognition (Aguirre et al., 1998; Bellon et al., 2000; Louette and Smale, 1998; Perales et al., 2003a, b; Smale et al., 1999). Teosinte data is from Sanchez-Gonzalez and RuizCorral (1996) and Sanchez-Gonzalez et al. (1998), who analyzed most of the information from collections made in the 1940s, through 1970s and up to 1995, when most of the teosinte accessions were confirmed in the locations described here.

The database was processed with INFO-ARC program installed in a UNIX system platform. The map of Mexico generated with this program and the maize and teosinte databases is shown in Figure 1.

\section{RESULTS AND DISCUSSION}

\section{Scenarios of dispersion of transgenes to maize and teosinte in Mexico}

\section{Diversity and production of maize}

The most fundamental characteristic of maize populations in Mexico is their diversity, still present in most regions of the Mexican territory (Aguirre et al., 1998). At the same time, traditional agricultural practices in small farmer and campesino communities in Mexico are widespread and highly open to seed exchange (Louette, 1997). Maize diversity is kept in gene banks with more than 9000 maize seed accessions from 64 catalogued landraces of Mexico (Cárdenas, 1997; LAMP, 1992; Taba, 1995a). Most of the seed collected came from ethnobotanical surveys in campesino maize fields and in local markets (HernandezXolocotzi, 1985; Wellhausen et al., 1952).

Of the 64 landraces collected in Mexico, 41 are still extant in maize producing areas. Gene banks or ex situ conservation is of utmost importance; however, it is recognized that this static type of conservation should be complemented with in situ conservation because "crop populations continue their evolution in response to human and natural selection" (Bellon and Smale, 1998). On-farm conservation of crop genetic resources is considered increasingly important as complementary to ex-situ conservation (Altieri and Merrick, 1987; Bellon et al., 1997).

Maize production regions in Mexico are fairly constant; however, specific locations for maize cultivation within maize production macro-regions could be highly variable due to economic constraints or changes in land use (Nadal, 1999). In addition, maize production areas have a high degree of geographical patchiness produced by the extremely low size of farmer's field, less than 2 ha 


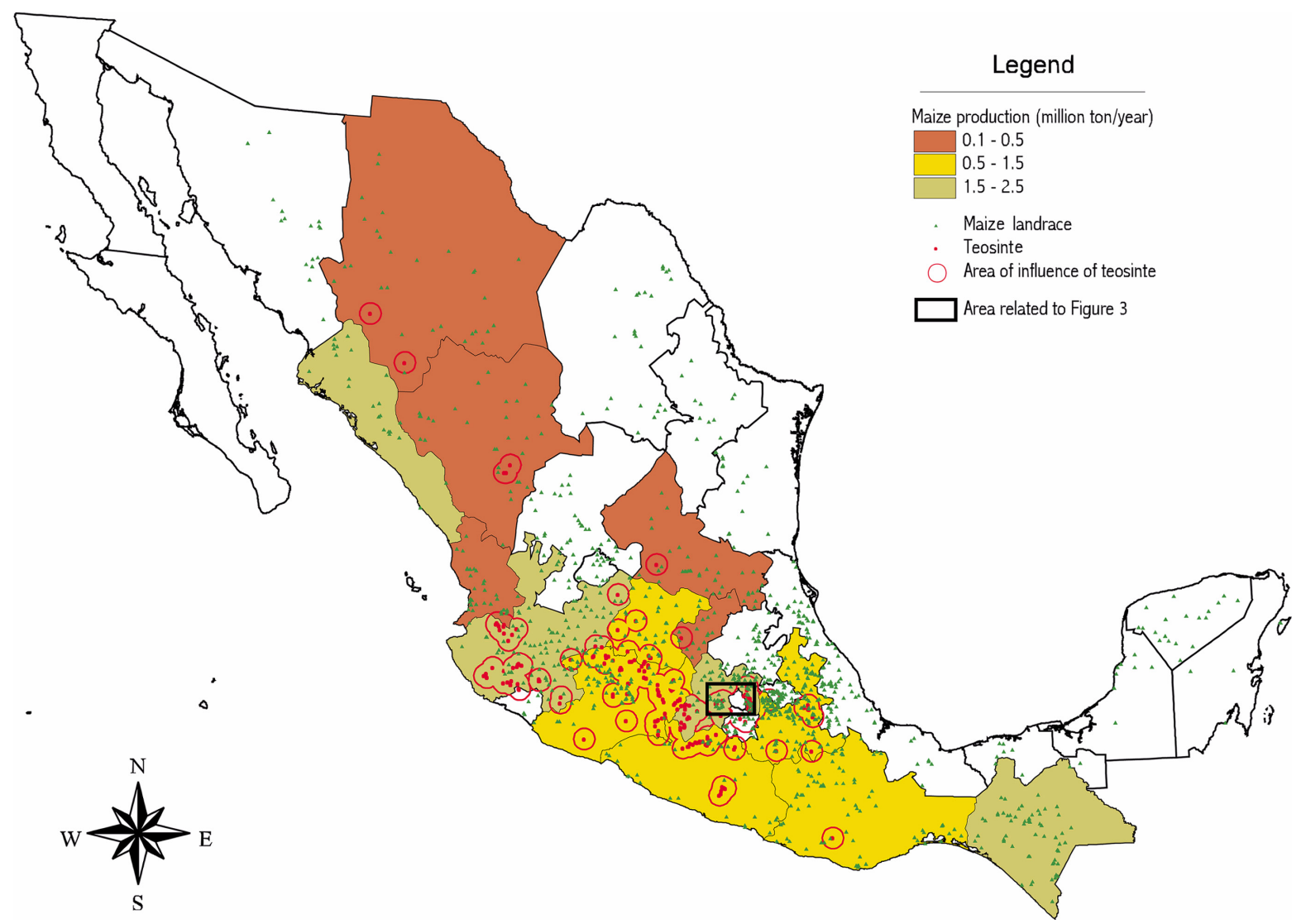

Figure 1. Map of Mexico with location of maize landraces and teosinte collection sites. States with major production of maize and those with reported teosinte collections are indicated on the map.

on average. Another important characteristic of maize production in Mexico is that at least $75 \%$ of the land dedicated to maize production is sown with local open-pollinated varieties, landraces, creolized materials, and some forms of traditional landraces or advanced combinations of these with improved varieties (Ortega-Paczka et al., 2000). Aguirre-Gomez et al. (1998) found that landraces are the dominant type of maize in four contrasting environments with varied agricultural productivity potential and infrastructure development in the State of Guanajuato (Bajio region). They also found that use of improved varieties was low but steadily increasing, and that the diversity richness of maize populations is likely associated with maize yield potential. On the contrary, it was observed (Aguirre-Gomez et al., 1998) that evenness of maize populations is associated with the presence of infrastructure, which could explain the trend of increasing substitution of landraces by improved varieties, sorgum or vegetables, observed in some locations of Bajio (Ortega-Paczka et al., 2000). Aguirre-Gomez et al. (1998) also stated that maize diversity in environments with low productivity potential and high availability of infrastructure may be high but fragile, therefore implying susceptibility to genetic erosion in these regions.

Traditionally, farmers plant their field with seed they save from their own harvest and some that is exchanged or traded with neighbors in their community, and therefore seed migration between fields (or seed lots) is the common rule (Louette, 1997). On the other hand, the remaining $25 \%$ of maize is produced in more industrialized agriculture of the states of Sinaloa and Jalisco (Tab. 1 and Fig. 1), where the use of improved varieties is increasing. In the states of Chiapas, Mexico and Michoacan (Tab. 1 and Fig. 1) there is also a high level of production of maize but, interestingly, the use of hybrids or improved materials is quite low (Nadal, 2000). 
Table 1. Maize production data for the States of Mexico with known populations of teosinte. Data from Sanchez-Gonzalez et al. (1998), and Nadal (1999, 2000).

\begin{tabular}{lcccccc}
\hline \hline State & $\begin{array}{c}\text { Total maize } \\
\text { production } \\
\text { (Million ton/year) }\end{array}$ & $\begin{array}{c}\text { Local maize produc- } \\
\text { tion for the state } \\
\text { (Million ton/year) }\end{array}$ & $\begin{array}{c}\text { Commercial maize } \\
\text { production in the state } \\
\text { (Million ton/year) }\end{array}$ & $\begin{array}{c}\text { Production of maize in } \\
\text { districts with teosinte } \\
\text { (Million ton/year) }\end{array}$ & $\begin{array}{c}\text { Maize yield in } \\
\text { districts with } \\
\text { teosinte (ton/ha) }\end{array}$ & $\begin{array}{c}\text { Number of } \\
\text { teosinte popula- } \\
\text { tions in the state }\end{array}$ \\
\hline JALISCO & 2.231 & 1.020 & 1.212 & 0.144 & 1.78 & 29 \\
MEXICO & 2.147 & 1.444 & 0.703 & 0.081 & 1.29 & 35 \\
MICHOACAN & 1.293 & 0.780 & 0.514 & 0.145 & 1.10 & 58 \\
GUERRERO & 1.112 & 0.864 & 0.249 & 0.056 & 1.20 & 29 \\
PUEBLA & 1.064 & 0.734 & 0.330 & 0.030 & 1.08 & 8 \\
GUANAJUATO & 0.824 & 0.469 & 0.355 & 0.039 & 0.89 & 9 \\
OAXACA & 0.721 & 0.579 & 0.141 & 0.002 & 0.88 & 1 \\
CHIHUAHUA & 0.304 & 0.170 & 0.133 & 0.003 & 0.68 & 1 \\
DURANGO & 0.291 & 0.174 & 0.117 & 0.029 & 1.17 & 3 \\
NAYARIT & 0.226 & 0.113 & 0.113 & 0.012 & 2.26 & 2 \\
QUERETARO & 0.186 & 0.143 & 0.043 & 0.011 & 0.80 & 1 \\
SAN LUIS POTOSI & 0.161 & 0.125 & 0.036 & 0.006 & 0.57 & 1.32 \\
MORELOS & 0.116 & 0.050 & 0.066 & 0.005 & & 4
\end{tabular}

\section{Maize landraces and transgenic maize release scenario}

In order to illustrate the scenario of open release of deregulated transgenic maize in Mexico, let us consider a simple model of diffusion with the logistic function. We assume that in a population of $k$ maize seeds planted in several areas within a district (i.e. several independent fields of varying sizes within a locality), $x(t)$ is the transgenic maize while $k-x(t)$ is the local maize planted. If we assume that transgenic and local maize mix homogeneously within independent fields, then the number of possible contacts that can spread the transgenes after pollination of local maize in each field is $x(k-x)$. A fraction of successfully fertilized eggs and seed obtained within each field produce the basic new transgenic maize population through different proportions of heterozygous and homozygous seed sets in each maize ear. Maize seeds produced in farmer's fields therefore have the first opportunity to disperse farther within the community through the network of local trade or marketing. Thus, the growth rate of the number of new transgenic maize, mostly heterozygous, is:

$$
\begin{aligned}
& \mathrm{d} x / \mathrm{d} t=a x(k-x)=r x(1-x / k) \\
& x(t)=\left[x(0) \mathrm{e}^{r t}\right] /\left[1+x(0) / k\left(\mathrm{e}^{r t}-1\right)\right]
\end{aligned}
$$

where $a$ and $r=a k$ are constants. The solution (2) of the differential equation (1) was used to generate graphs that illustrate the percentage of area covered by transgenic plants through the years (Fig. 2). Since $r$ is a constant we are thus assuming that the same rate of increase would be reached at each time cycle.

A preliminary hypothesis could be drawn from the analysis of this simplified model. The speed of dispersion of transgenes depends on the size of the area planted to maize (i.e. number of plants, $k$ ) within the district, as well as on the initial number of transgenics planted within that area; that is, the lesser the area planted to maize, together with a greater number of transgenic maize planted, the faster the spread of transgenes. For example (Figs. 2 and 3 ), if transgenic maize were planted in only 1 ha of the district of Juchitepec (Mexico), which has 2499 ha $(k)$ sown to maize, and assuming a rate of "diffusion" $(r)$ of 1 , it could be expected that after 10 years 2244 ha $(89.8 \%$ of the area planted to maize) within the district would be covered with homozygous, heterozygous, backcrosses and different generations of transgenic maize. While, if transgenic maize were planted in 1 ha of the district of Toluca (Mexico), having 12633 ha $(k)$ planted to maize, after 10 years at a rate of "diffusion" $(r)$ of 1 the area covered with transgenic maize would be 8029 ha, which is $63.6 \%$ 


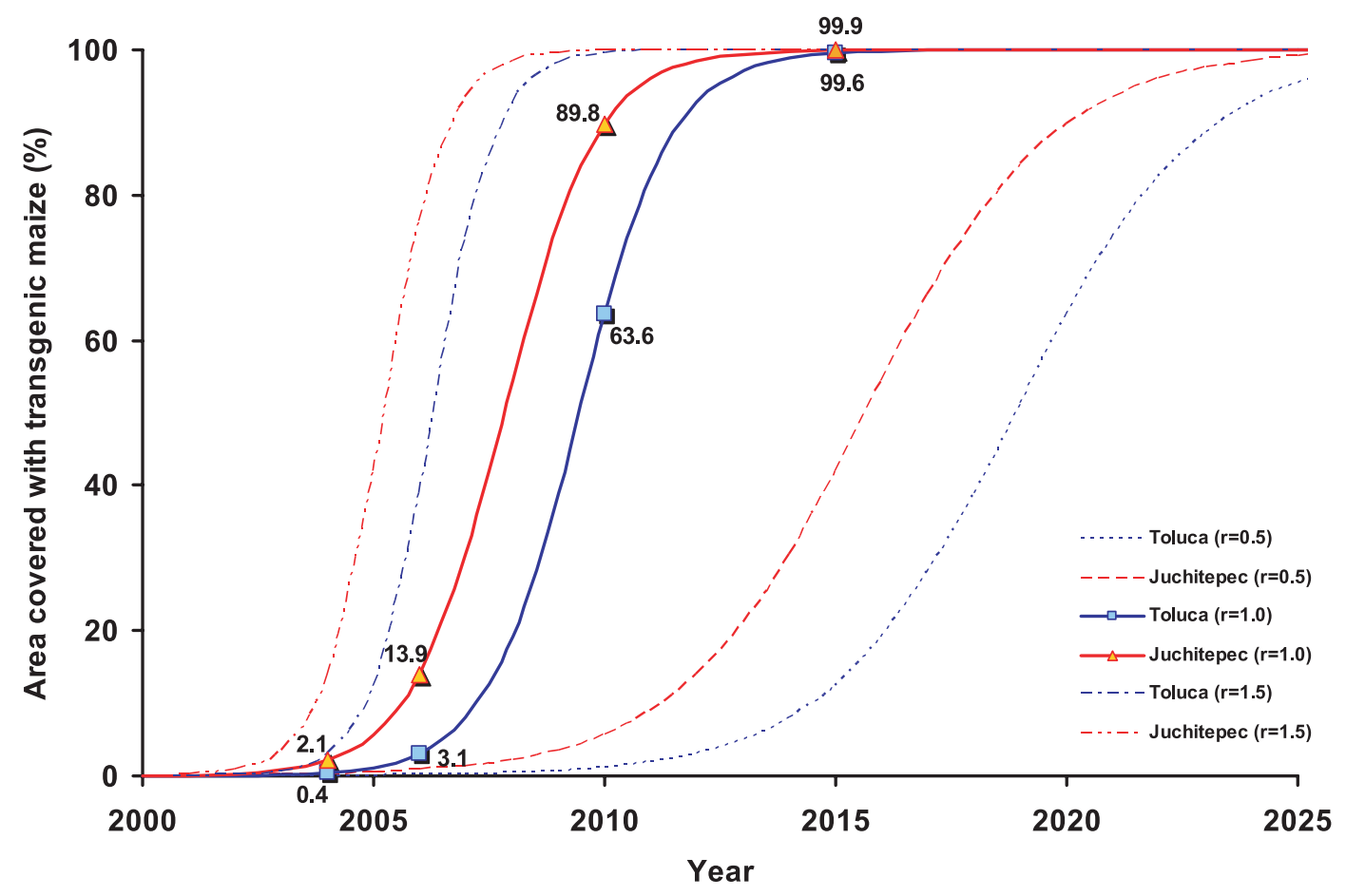

Figure 2. Trajectories of accumulation of transgenic maize in two districts of Mexico, based on the logistic function as explained in the text. Initial sowing of transgenic seed is one hectare in each district. There are three dispersal rates in this illustration: $r=0.5,1.0$, and 1.5 .

of the area planted to maize. Figure 2 shows the form of the trajectories through time in the case of three different rates of diffusion ( $r=0.5,1.0$ and 1.5) for two districts, Toluca and Juchitepec, with different carrying capacities (k) and initially with 1 ha planted in the year 2000 to transgenic maize in each district. Our rate of "diffusion" or "dispersal", $r$, is the composition of functions ascribed to pollen dispersal within maize fields, with contiguous areas, and seed exchange among neighbor farmers in rural communities producing maize. There is no attempt in this model to differentiate, or make explicit, each component of the dispersal rate $(r)$, and thus they are pooled together in a single value. Since farmers do not actually select transgenic maize because they cannot visually recognize it, there is no Ostrinia nubilalis (European corn borer) in their fields, and poor farmers do not use herbicide at all, we are assuming a lack of human selection that makes transgene "dispersal" resemble epidemic propagation. Our example also (Fig. 3) regards each municipality as enclosed within boundaries, but this is just for illustration, in reality the analysis of specific situations must consider whole regions of maize production, without political borders, defined by eco-geographic, environmental, and social conditions. Also, as with most simple deterministic models, the underlying assumption is that dispersal is the cumulative outcome of many small steps (Levin, 1986).

In the open agricultural system predominant in Mexico, transgenic maize and the diverse types of maize in different regions (i.e. landraces, creoles, and mixtures) will definitely interact, and gene flow in both directions could occur in all areas where transgenic maize would be sown if it were deregulated. According to our model, genetic exchange between local landraces and transgenic maize would intensify after few cultivation seasons. This would initially concern the two already available GM maize traits, herbicide tolerance and resistance to lepidopteran insect infestation. These transgenes would be readily integrated into the local maize material being managed by most communities, since gene flow would be within the same species.

Transgene introgression is likely to happen in the states where traditional agriculture is widespread. Farmers cultivating maize in small communal fields and frequently exchanging seed with neighbors would have a high probability of transgene incorporation in their maize, through hybridization, leading to introgression in further generations, first in their fields, and then within the localities of a district. 


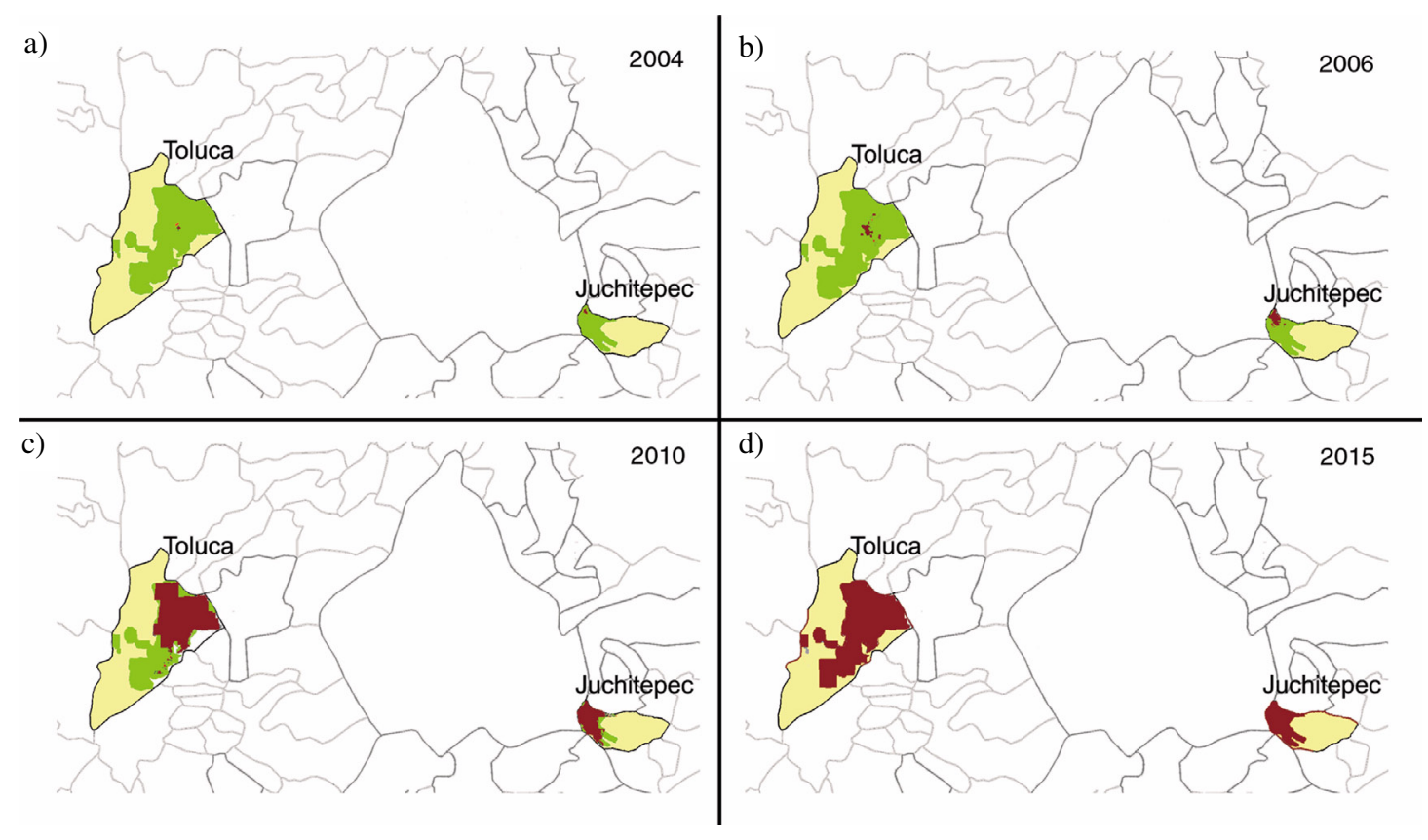

Figure 3. Simulation of transgenic maize dispersal in selected districts. Maize production areas are in green (grey in B\&W). Dark red color (black in B\&W) represents areas with transgenic maize after a simulated initial planting of one ha in the year 2000 (see Fig. 2). (a) Year 2004; (b) Year 2006; (c) Year 2010; (d) Year 2015.

Some maize production areas have been surveyed, and these surveys have been updated for the presence of landraces. In the Central Valleys of Oaxaca there are Bolita complex, and Tepecintle landraces of maize (Smale et al., 1999). In the region of Cuzalapa, State of Jalisco, Louette and Smale (1998) recognized the presence of Tabloncillo and Tabloncillo-Perla landraces of maize, and, in their study of the Bajio region, Aguirre-Gomez et al. (1998) found a total of 152 samples of maize races, 86 racial mixtures and 9 creolized materials. This information supports the assumption that in most Mexican maize production macro-regions, landraces described in Wellhausen et al. (1952) and summarized in LAMP (1992) could exist, with varying degrees of mixture.

Based on this simple model, it can be foreseen that the fate of transgenic maize in Mexico, if it were commercially available and released into the agroecosystem, would be its incorporation in the genetic pool of the Mexican maize germplasm. There is a high likelihood of this outcome, if is considered that transgenic maize would be exchanging genetic information with a great variety of landraces and creolized materials, which so far have been interacting with other types of improved materials and hybrids. Seed recycling in Mexico is common in small farm communities, and this allows a high level of genetic migration once trade and seed exchange starts operating. Migration occurs at the community level and at a broader level between regions fed by the recycling of commercial varieties (hybrids and open pollinated varieties). Locally, farmers adapt varieties to their changing conditions (agroecology and market) providing suitable conditions for this system to integrate new genes into the pool. These same system factors make it far more complicated to have genes eradicated. Thus, it should be kept in mind that transgenes close to being inserted in the maize genome, in addition to new versions of $B t$ and herbicide tolerance, include ones encoding vaccines, degradable plastic products, quality protein genes, aluminum tolerance, apomictic genes, together with mutator regulating elements from landraces of maize (i.e. Zapalote Chico). As a consequence, the risk/ benefit of release such transgenic maize would have to be analyzed closely.

Classical theory of evolution points out that gene flow is capable of counteracting other evolutionary forces like mutation, drift and selection. In modern industrial agriculture a stand of maize could contain a million plants (Ellstrand et al., 1999), and under these conditions gene flow from transgenic maize to local landraces is expected 
to be very high. Under these conditions, the rate of incorporation of foreign alleles after hybridization is likely to be orders of magnitude higher than typical mutation rates.

\section{Teosinte and transgenic maize scenario}

In several regions maize and teosinte are sympatric, and the latter is found in areas where maize is most densely cultivated (Fig. 1 and Tab. 1). Mexican annual teosintes can be separated in three races according to Wilkes (1977) or two subspecies (Taba, 1995b), Zea mays subspecies parviglumis or Balsas race; Zea mays subspecies mexicana (for the Central Plateau and Chalco races). The relationships between these three races and maize are different: the Chalco race is essentially a weed maintained by cultivation, the Balsas race is a wild plant with some interaction with maize that is cultivated in the same areas. Central Plateau corresponds to an intermediate case, being wild or weed depending on the populations observed. It should also be pointed out that maize and some teosinte populations have been sympatric for a long time (Pope et al., 2001). The amount of gene flow between maize and either Zea mexicana or Zea parviglumis depends on the isolation from and overlap with maize, in flowering time in populations of each subspecies. Natural hybridization between landraces of maize and teosinte in some areas of Mexico has been observed (Sanchez-Gonzalez and Ordaz, 1987), which suggests that introgression from maize to teosinte cannot be precluded. This could be an explanation for the presence of the $c l$ allele found in Chalco teosinte. This allele probably was acquired by teosinte through gene flow from maize landraces in this area, which have $c l$ at a high frequency (Hanson et al., 1996). Therefore, gene flow between maize and two teosinte subsp., Zea mexicana and Zea parviglumis, is greater than zero, since they are cross compatible, spatially sympatric and do overlap in flowering time (Sanchez-Gonzalez and Ordaz, 1987).

If transgenic maize were deregulated and authorized for commercial release in Mexico, its interaction with teosinte would not be significantly different from the one already present in areas of production where teosinte coexists sympatrically with maize. In this scenario, gene flow from teosinte to transgenic maize would have no consequences, since gene flow from teosinte into maize has been present without affecting maize populations. Gene flow from transgenic maize into Zea mexicana and Zea parviglumis, on the other hand, may also be greater than zero, but in this case transgenes such as herbicide resistance or insecticidal protein could produce unpredictable consequences in the agroecosystem web.
Maize production as related to the number of teosinte populations in Mexico is shown in Table 1. Thus, if it is assumed that there is at least some degree of hybridization from teosinte to maize, and the reciprocal, in the areas where there are known populations of teosinte (Fig. 1), the rate of hybridization would exceed $1 \%$ over distances $100 \mathrm{~m}$ or more (Ellstrand et al., 1999). This would be particularly the case in maize fields under intensive commercial agriculture (Tab. 1), and therefore introgression is likely to eventually show up in scattered locations within those areas. In this scenario there are 186 known and confirmed teosinte populations sympatric with maize in 465000 hectares producing 569494 ton/year, which are located in a total of 99 districts in 14 states of Mexico (Tab. 1). In most of these maize production areas there is a substantial number of known landraces of maize and creolized materials (Aguirre-Gomez et al., 1998; Louette, 1997; Perales et al., 2003a, b; Sanchez-Gonzalez and Ordaz, 1987).

The possible outcomes of interactions between different crops, maize included, and their wild relatives are described by Ellstrand et al. (1999). Nevertheless, regarding the relationship between maize and teosinte, specific hypotheses can be included in this analysis.

If neutral gene flow occurred, the level of neutral variation in teosinte would probably be enhanced through the incorporation of the genetic variation contained in maize open pollinated landraces that are assumed to be able to hybridize with transgenic maize.

In a different scenario, local varieties hybridizing with transgenic maize by means of gene flow or seed dispersion by farmer's exchange, which generates progeny with novel traits, could exert a strong selection against teosinte if alleles from the novel source, in this case hybrids between local varieties crossed to transgenic maize, were detrimental. This outcome could be expected in areas (districts) with above average maize production (Tab. 1 and Fig. 1), because the greater fraction of maize immigrants relative to the total teosinte population per generation would swamp locally adapted alleles of teosinte populations. In the sympatric areas of coexistence of these species, outbreeding depression due to extreme differences in adaptation between maize (completely dependent on cultivation) and teosinte (wild feral species), would arise.

In the case that beneficial gene flow were present, fixation of domesticated favorable alleles from maize into teosinte population could speed up.

Using the same model previously applied, assuming that 1 ha of transgenic maize were planted in each one of the districts where known teosinte populations are located (467 261 ha), with a dispersal rate of 1 , it is estimated that 


\section{J.-A. Serratos-Hernández et al.}

after 5 years the total area covered with transgenic maize mixed with local varieties would be around 7336 ha $(1.57 \%)$. Similarly, if five hectares of transgenic maize were planted in each one of these districts with a dispersal rate $r=1$, then a total of 410488 hectares $(87.85 \%)$ would be covered with transgenic maize after 10 years. Thus, it is foreseen that in the event of transgenic maize released in districts where known teosinte populations are present, the likelihood of transgene transfer into teosinte populations increases exponentially with time.

From the previous discussion of landraces-transgenic maize-teosinte scenarios, some further questions arise. When genetically modified maize enters this system, how would the dispersal of transgenes be controlled and eliminated if this would be required? It will become very difficult to have certified GMO-free maize, if the market imposes this guarantee or if this opens new markets. Other types of GM maize are in the pipeline. How we would control the flow of many new genes that could be accumulating in the local farmers varieties? How could we be sure of non-interference between transgenes once they are all in the same plant?

Transposons and retrotransposons are present in the maize genome. Some are active and induce new mutations. At least in one race in Mexico, the presence of an active MuDR has been demonstrated (Gutierrez et al., 1998). Regulation of their activity is through genetic mechanisms that could also be active for transgenes (silencing by methylation). What we could expect from the interaction of active transposons, retrotransposons on transgenes from transgenic maize?

The null hypothesis for all these questions is that no differences between "resident" genes and transgenes would be observed. The challenge is to test this hypothesis through experimentation.

\section{CONCLUSIONS}

The maize production agroecosystem in Mexico has distinctive characteristics that make suitable a scenario including the incorporation and exchange of novel sources of alleles (transgenes). Farming conditions in Mexico relying on traditional open pollinated maize varieties, maintained and managed by campesinos, shape an open system that since domestication of maize has created the great diversity of the crop. This is a very different system (genetically, socially and economically) from the one at work in countries with industrialized agriculture.

Without assigning any value judgment, either good or bad, to transgenic maize, the most likely outcome of deregulation and field release of GM maize in Mexico would be the incorporation of transgenes in the genome of Mexican germplasm and perhaps in the genome of its wild relative, teosinte. This conclusion arises from applying the simple logistic function that accounts the open genetic characteristics of the maize agroecosystem by combining pollen and seed dispersal in a single parameter $(r)$.

There will be many implications for the biology, agronomic, legal and cultural aspects of maize landraces in Mexico if transgenic maize is not regulated. It is foreseen that in the near future, new biotechnology developments will represent a major challenge for the biosafety assessment of GM maize. Therefore, it seems advisable to move forward in the implementation of a national monitoring system, and the active participation of all the actors involved.

Received April 1, 2004; accepted August 11, 2004.

\section{REFERENCES}

Aguirre-Gomez JA, Bellon MR, Smale M (1998) A regional analysis of maize biological diversity in Southeastern Guanajuato. Economics Working Paper 98-06, CIMMYT, Mexico

Altieri MA, Merrick LC (1987) In situ conservation of crop genetic resources through maintenance of traditional farming systems. Econ. Bot. 41: 86-96

Bellon M, Smale M (1998) A conceptual framework for valuing on-farm genetic resources. Economics Working Paper No 98-05, CIMMYT, Mexico

Bellon MR, Pham JL, Jackson MT (1997) Genetic conservation: A role for rice farmers. In Maxted N, FordLloyd BV, Hawkes JG, eds, Plant Conservation: The in situ approach, Chapman and Hall, London

Bellon MR, Smale M, Aguirre A, Taba S, Aragón F, Díaz J, Castro H (2000) Identifying appropriate germplasm for participatory breeding: An example from the Central Valleys of Oaxaca. Economics Working Paper 00-03, CIMMYT, Mexico

Berg P, Baltimore D, Boyer HW, Cohen SN, Davis RW, Hogness DS, Nathans D, Roblin R, Watson JD, Weissman S, Zinder ND (1974) Potential biohazards of recombinant DNA molecules. Science 185: 303

Cárdenas F (1997) Mexico Report. In Taba S, ed, Latin American Maize Germplasm Regeneration and Conservation: Proceedings of a Workshop, Maize Program Special Report, CIMMYT, Mexico

Ellstrand NC, Prentice HC, Hancock JF (1999) Gene flow and introgression from domesticated plants into their wild relatives. Ann. Rev. Ecol. Syst. 30: 539-563

Gutierrez-Nava M, Warren CA, León P, Walbot V (1998) Transcriptionally active $M u D R$, the regulatory element of the 
mutator transposable element family of Zea mays, is present in some accessions of the Mexican land race Zapalote Chico. Genetics 149: 329-346

Hanson MA, Gaut BS, Stec AO, Fuerstenberg SI, Goodman MM, Coe EH, Doebley JF (1996) Evolution of anthocyanin biosynthesis in maize kernels: The role of regulatory and enzymatic loci. Genetics 143: 1395-1407

Harlan JR (1992) Crops and man. ASA, Wisconsin

Hartkamp AD, White JW, Rodriguez-Aguilar A, Banziger M, Srinivasan G, Granados G, Crossa J (2000) Maize Production Environments Revisited: A GIS-based Approach. CIMMYT, Mexico

Hernandez-Xolocotzi E (1985) Maize and man in the greater southwest. Econ. Bot. 39: 416-430

Hyman G, Jones P, Lema G (1998) Latin America Crop Distribution Database CD-ROM. CIAT, Colombia

LAMP (1992) Data of the Latin American Maize Project CDROM. CIMMYT Mexico

Levin SA (1986) Ecological and evolutionary aspects of dispersal. In Teramoto E, Yamaguti M, eds, Mathematical topics in population biology, morphogenesis and neurosciences, Proceedings of an international symposium, Springer-Verlag, Berlin, pp 80-87

Louette D (1997) Seed exchange among farmers and gene flow among maize varieties in traditional agricultural systems. In Serratos JA, Willcox MC, Castillo F, eds, Gene flow among maize landraces, improved maize varieties, and teosinte: Implications for transgenic maize, CIMMYT, Mexico

Louette D, Smale M (1998) Farmers' seed selection practices and maize variety characteristics in a traditionally-based Mexican community. Economics Working paper 98-04, CIMMYT, Mexico

Martínez-Soriano JP, Leal-Klevezas DS (2000) Transgenic maize in Mexico: No need for concern. Science 287: 1399

Nadal A (1999) El maíz en México: Algunas implicaciones ambientales del Tratado de Libre Comercio de América del Norte. In Comisión para la Cooperación Ambiental, eds, Evaluación de los efectos ambientales del Tratado de Libre Comercio de América del Norte, Montreal

Nadal A (2000) The environmental and social impacts of economic liberalization on corn production in Mexico. OXFAMGB-WWF-International, Oxford

Nigh R, Benbrook C, Brush S, Garcia-Barrios L, OrtegaPaczka R, Perales HR (2000) Transgenic crops: A cautionary tale. Science 287: 1927

Ortega-Paczka R, Martinez-Alfaro MA, Sanchez-Gonzalez JJ (2000) Recursos fitogeneticos autoctonos. In Ramirez P, Ortega R, Lopez A, Castillo F, Rincon F, Zavala F, eds, Recursos Fitogeneticos de Mexico para la Alimentacion y la Agricultura, Informe Nacional. SNICS-SOMEFI, Chapingo, Mexico, pp 33-34
Perales-R H, Brush SB, Qualset CO (2003a) Landraces of maize in Central Mexico: An altitudinal transect. Econ. Bot. 57: 7-20

Perales-R H, Brush SB, Qualset CO (2003b) Dynamic management of maize landraces in Central Mexico. Econ. Bot. 57: 21-34

Pope KO, Pohl MED, Jones JG, Lentz DL, von-Nagy C, Vega FJ, Quitmyer IR (2001) Origin and environmental setting of ancient agricuture in the lowlands of mesoamerica. Science 292: 1370-1373

Sanchez-Gonzalez JJ, Ordaz L (1987) El teocintle en México: distribución y situación actual de las poblaciones. Systematic and Ecogeographic Studies on Crop Gene Pools 2, IBPGR, Rome

Sanchez-Gonzalez JJ, Goodman MM (1992a) Relationships among the mexican races of maize. Econ. Bot. 46: 72-85

Sanchez-Gonzalez JJ, Goodman MM (1992b) Relationships among mexican and some North American and South American races of maize. Maydica 37: 41-51

Sanchez-Gonzalez JJ, Ruiz-Corral JA (1996) Distribución del teocintle en México. In JA Serratos, Willcox MC, Castillo F, eds, Flujo genético entre maíz criollo, maíz mejorado y teocintle: implicaciones para el maíz transgénico, CIMMYT, Mexico, pp 20-38

Sanchez-Gonzalez JJ, Kato-Yamakake TA, AguilarSanmiguel MA, Hernandez-Casillas JM, LopezRodriguez A, Ruiz-Corral JA (1998) Distribucion y caracterizacion del teocintle. Libro tecnico 2, Instituto Nacional de Investigaciones Forestales, Agricolas y Pecuarias, Guadalajara

Smale M, Aguirre A, Bellon M, Mendoza J, Manuel-Rosas I (1999) Farmer management of maize diversity in the Central Valleys of Oaxaca, Mexico: CIMMYT-INIFAP 1998 Baseline socioeconomic survey. Economics Working Paper 99-09, CIMMYT, Mexico

Taba S (1995a) Maize germplasm: Its spread, use, and strategies for conservation. In Taba S, ed, Maize Genetic Resources, Maize Program Special Report, CIMMYT, Mexico

Taba S (1995b) Teosinte: Geographic variations and conservation. In Taba S, ed, Maize Genetic Resources, Maize Program Special Report, CIMMYT, Mexico

Tiedje JM, Colwell RK, Grossman YL, Hodson RE, Lenski RE, Mack RN, Regal PJ (1989) The planned introduction of genetically engineered organisms: ecological considerations and recommendatios. Ecology 70: 298-315

Wellhausen EJ, Roberts LM, Hernandez-Xolocotzi E, Mangelsdorf PC (1952) Races of maize in Mexico. Harvard University, Cambridge, USA

Wilkes HG (1977) Hybridization of maize and teosinte, in Mexico and Guatemala and the improvement of maize. Econ. Bot. 31: 254-293 